\title{
Domestic Resource Mobilization and Under-Five Mortality in Nigeria
}

\author{
Obindah Gershon ${ }^{1,2}$, Adesuwa Akhigbemidu² \& Romanus Osabohien ${ }^{1,2}$ \\ ${ }^{1}$ Department of Economics and Development Studies, Covenant University, Ota, Nigeria \\ ${ }^{2}$ Centre for Economic Policy and Development Research (CEPDeR), Covenant University, Ota, Nigeria \\ Correspondence: Romanus Osabohien, Department of Economics and Development Studies, Covenant University, \\ Ota, Nigeria. E-mail: romanus.osabohien@ covenantuniversity.edu.ng
}

Received: March 16, 2020

Accepted: April 20, 2020

Online Published: June 27, 2020

doi:10.5430/rwe.v11n3p320

URL: https://doi.org/10.5430/rwe.v11n3p320

\begin{abstract}
This study considered domestic resource mobilisation and allocation to healthcare service delivery due to the high rate of infant deaths in Nigeria. Value addition in the agricultural sector is captured as a major source of revenue which could be channelled towards increased government expenditure in healthcare. As such, the paper applies vector error correction technique on yearly data for the period 1981 to 2015. It investigates the long-run relationship and short-run dynamics between under-five mortality on the one hand, with female literacy, agricultural productivity, tax revenue, and gross capital formation on the other hand. Outcome of the study indicates, from a long run perspective, under-five mortality is positively related to tax revenue, female literacy rate and gross capital formation. However, there is a negative relationship between under-5 mortality and agricultural productivity. Moreover, as Nigeria diversifies away from crude oil towards agriculture, increased productivity and tax revenues could be channelled towards better health outcomes and rural transformation. Furthermore, enhanced management of tax and better budgeting towards the agricultural sector is recommended. In addition, infrastructure development, agro-allied investments will ensure reduction in agricultural waste and supply costs. The outcomes portend significant relevance for meeting Sustainable Development Goals 2, 3, 4, \& 10.
\end{abstract}

Keywords: domestic resource mobilization, under-five mortality, female literacy

JEL Classification: H51, H60, I18

\section{Introduction}

Healthcare expenditure, according to Musango, Nabyong, Elovainio \& Cheruiyot (2013) is a form of investment in human capital which has contributed to development in countries like Singapore, South Korea and Taiwan. In this regard, however, hydrocarbon-rich countries like Angola, Nigeria and Venezuela, have trailed. This highlights as an essential factor in a country's financial and socio-economic change (Osabohien, Matthew, Gershon, Ogunbiyi, \& Nwosu, 2019; Efanga \& Nwokomah, 2013).

Meanwhile, a challenging factor in Nigeria's human capital development is inadequate healthcare investment and education spending. Actually, public sector expenditure in basic social amenities and human development services (like electricity) is low in Nigeria (Gershon \& Patricia, 2019, Riman \& Akpan, 2012). Most developed and developing nations share similar healthcare objectives (in terms of distribution and level) as in Sustainable Development Goal 3 (SDG3) (UN, 2017; Roberts, Hsiao, Berman \& Reich, 2004). It is important to emphasize that healthcare objectives are beyond basic macroeconomic studies that focus on efficiency but mostly downplay the value of human life (Sassi, Le Gran \& Archard, 2001) but this has been highlighted by the COVID-19 pandemic.

However, given healthcare funding deficiencies, poor healthcare outcomes (like high maternal mortality, low number of doctors per capita, high infant mortality, low access to essential medical services and low life expectancy) are prevalent in many developing countries. It has been argued that developing countries need to spend an average of US\$44 per capita to provide effective human services (Musango, Nabyong, Elovainio \& Cheruiyot, 2013).

Domestic resource mobilization (tax, savings, remittance) grew by an average of 3.26 percent from 1981 to $1985,75.68 \%$ from 1986 to 1990 and $421.10 \%$ from 1991 to 1995 . Thereafter, it declined to $86.82 \%$ from 1996 to 2000 and $180.95 \%$ from 2001 to 2005. Then, it declined to an average of 69.01\% from 2006 to 2010, and 38.05\% from 2011 to 2014 (Oyinlol, Adedeji and Bolarinwa, 2020; World Development Indicators, 2015). Moreover, evidence from studies on health 
expenditure and economic growth shows that significant improvement in health of populations could reduce poverty and inequality between developing and developed economies (Bloom \& Canning, 2005; Bloom, Canning \& Sevilla, 2004; Carr, 2004; Finlay, 2007; Wagstaff, 2002). Estimates have it that 50-80\% of resources needed to finance the sustainable development goals will have to be sourced domestically (WHO, 2015).

Domestic resource mobilization (DMR) is essential for achieving sustainable development goals (Onyinlola et al. 2020; Culpeper \& Bhushan; 2008, WHO, 2002; Bhushan and Samy, 2010) but has remained slow in Africa (Wujung, Vukengkeng, Aziseh, Fozoh Isiah, 2015; Fakile, Adeniran \& Samuel, 2014; Culpeper \& Bhushan, 2008). Moreover, the interaction of domestic resource mobilization and health outcome in Nigeria has remained extensively unexamined. This study examines the effect of domestic resource mobilization on health outcome in Nigeria and contributes to existing literature by incorporating the agricultural sector (Otsuka, Estudillo, \& Yamano, 2010).

Many studies on health outcomes (Matthew eet al. 2018; Matthew, 2015; Fans \& Saurkar, 2008; Xu \& Saksena 2011) focused on public expenditure, increasing tax efficiency or setting minimum budget appropriation for health without considering sources of increased government revenue. However, no consideration has been given to agricultural sector as a sustainable source of domestic resource. Following the Nigerian government's diversification endeavours, the agricultural sector is expanding and becoming more profitable. More so, agricultural activities are useful avenues for medical and pharmaceutical research/employment - thereby reducing unemployment and indirectly infant mortality. This study focuses attention on how increased agricultural productivity is a potential source of domestic resources that could be channelled to the health sector for improved outcomes. Notably, most studies failed to examine how the private sector contributes to domestic resource mobilization concentrating only on the public sector (Ogunleye and Fashina, 2012; Gupta et al., 2001; Gakidou and King, 2000; Verhoeven and Tiongson, 1999).

This paper examines the effects of domestic resource mobilization (from agriculture) on health outcomes in Nigeria. Tax revenue from agricultural activities is conceptualized as domestic agricultural resource mobilization (DARM) for the health sector towards improving under-5 mortality rate. DARM is relevant to consider as it contributes towards poverty reduction and sustainable development. In addition, it offers the benefit of domestic policy ownership and better coherence with domestic needs. This study uniquely considers the potentials for increasing the fiscal space for healthcare funding towards meeting the health needs of the increasing Nigerian population. Specifically, the long-run relationship at the nexus of domestic resource mobilization (tax revenue and agricultural productivity) and health outcome is investigated.

Consequently, the extent to which agriculture contributes to domestic resource mobilization is examined. Towards achieving the stated objectives, the following hypotheses that are tested: Domestic Resource Mobilization does not improve health outcomes; Agriculture does not contribute to Domestic Resource Mobilization; and no long run relationship exists between health outcomes and domestic resource mobilization.

Annual time series data from World Bank Development Indicators and Central Bank of Nigeria are sourced - from 1981 to 2015. Under-five Morality Rate (UMR) is adopted as a proxy for health outcome in Nigeria, while agricultural productivity and tax revenue are adopted as possible domestic resource channels - other aspects of DRM are excluded. The study adopts Augmented Dickey Fuller (ADF) unit root test, Engel and Granger Co-integration test, Vector Error Correction Model (VECM), as well as, the Grossman model. The co-integration test is utilised to determine the presence of a long run relationship among key variables. VECM is used to estimate the speed at which the dependent variable (UMR) is restored to equilibrium after changes in the independent variables. Subsequently, the paper is structured as follows: definition of key terms; literature review (theoretical and empirical); model specification and estimation; presentation and discussion of results, application of findings and conclusion.

\section{Review of Theoretical and Empirical Literature}

Relying on the life cycle hypothesis (Modiglani, 1988; Kotlikoff, 1988) Grossman (1972), theorized about the link between domestic resource mobilization and health outcome. Grossman theory of the demand for health care captures the way by which private resources are distributed to produce health and the idea that individuals are not only consumers but also makers of health. The model includes investing resources into human capital which comprises of health and education. Health here is viewed as a capital good that can depreciate at a non-constant rate. The model explains the effect of key health determinants - age, income and education - on the demand for healthcare. For instance, income builds the capacity of an individual to demand for health care as they have more resources to dedicate to healthcare and other activities.

Grossman's model on the demand for health also viewed health demand comprises of two components which are the consumption and investment effects. Consumption effect has an immediate impact or satisfaction and is for the most part 
fleeting in nature - one may eat healthy food to feel better and healthier. The investment effect, however, has a long-term effect or an indirect utility - for example, one may take part in good exercise just for increased life span. A pertinent question is what proportion of the populace in low and medium-income countries can afford and derive both components of health demand?

Matthew, Adegboye and Fasina (2014) analysed spending on health and its impact on health outcomes in Nigeria. It was seen that several factors such as air contamination, hospitals, availability of satisfactory medications among others were recognised as being imperative in determining better health outcomes in Nigeria. This proved the Grossman health production functions holds true for lifetime investment in health in Nigeria. Lalitagauri (2015) utilising the Grossman model, argues that just expanding public expenditure in the health sector, may not essentially influence health outcomes if the effectiveness of such spending is poor. Furthermore, Dolan (2003) criticizes the model because of the following: the assumption that health care is a consistent life time investment, insurance markets were not recognised, the assumption that consumers have perfect information of marginal efficiency of capital (MEC) of health care, depreciation and interest rate. Cyprus (2015) descriptively analysed domestic resource mobilization in a Caribbean district and found that tax revenues represent the most significant source of development financing for Caribbean developing countries.

From an empirical perspective, literature shows that many studies have been undertaken on domestic resource mobilization and health outcome utilising various health indices - life expectancy, maternal mortality, under-five mortality - and estimation techniques. Ashraf, Glaeser, Holland and Steinberg (2017) highlights the effect of infrastructure on health outcomes by focusing on outages in water supply. The study, focused on Lusaka, provides evidence of association between increased outages and incidence of diseases. Furthermore, the study asserts that the effects of water supply outages and imperfect infrastructure go beyond health outcomes to young girl education - as in Nigeria and other African countries. However, the study ignores the resource allocation perspective of the issues considered. Amusa, Monkam \& Viegi (2015) focused on non-resource tax revenues in Nigeria and questions whether foreign aid does enhance domestic resource mobilization (DRM). The GMM technique was adopted using secondary time series data from 1980-2013. The study found out that the most effective tool for enhancing domestic resource mobilization is external aid in the form of loans.

Wujung, Vukengkeng, Fozoh (2015) investigated how economic growth in Cameroun has been affected by domestic resource mobilization. Utilising data from World Development Indicator, 2014 for the period of 1980-2013, the study adopted Instrumental Variable Generalised Method of Moments (IVGMM0 for regression analysis. It was concluded channels of DRM and economic growth have positive relationship that is significant in Cameroon. Matthew, Adegboye and Fagbeminiyi. (2014) analysed the link between Nigeria's health outcomes and government's expenditure on health, and discovered a noteworthy association between both variables.

Ogunleye and Fashina (2012) evaluated the necessities for domestic resource mobilization for sustained post-crisis recovery and growth in sub-Saharan Africa (SSA). The paper emphasised the need for DRM by examining the range of issues encompassing it in SSA. Arellano-Bond GMM technique on a panel of 38 SSA countries was adopted. The result showed that savings and investment are the main factors of DRM that contribute significantly to economic growth while all tax revenue variables considered are insignificant. It was suggested that there's a need for enhancing DRM Procedure. Likewise, Bokhari (2006) using an econometric proof connecting a nation's GDP per capita to two health outcomes: under-five mortality and maternal mortality. The result demonstrates that the versatility of under-five mortality as government uses ranges from -0.25 to -0.42 with a mean estimation of -0.50 . The outcome further suggests that while economic growth is positively a critical giver to health outcome, government spending on health is similarly an essential variable.

Bloom, Canning and Graham (2003) research shows increased life expectancy results in higher rate of savings up until even at retirement. Kageyama (2003) examine the effects of savings of a continuous raise in life expectancy on the level of savings in a cross-country study of 126 economies (including Nigeria) using Ordinary Least Square regression techniques. The study concluded that raising life expectancy at birth has a direct effect on saving rates in most of the economies studies.

This paper contributes to extant literature by conceptualising domestic resource mobilisation from a different point of view. In this context, agricultural sector is pivotal - more output generates series of agro-allied processes and in turn industries are established thereby leading to employment opportunities, income generation, profits and revenue to the government via corporate company tax, as well as, personal income tax. These in turn, lead to increased private savings available for private investment in healthcare services and possibly, increased government allocation to the health sector. 


\section{Methodology}

Described in this section is the methods and models used in the study, as well as, data sources, description, techniques of estimation, and related empirical issues.

\subsection{Model Specification}

The following model fundamentally captures aim of the study which examines the effect(s) of domestic resource mobilization on health outcome in Nigeria:

$$
Y=f(H)
$$

Where $Y$ is a social indicator reflecting health outcome (measured by under-five mortality rate), $H$ is the vector of explanatory variables. In its implicit form, the model can be expressed as:

$$
U M R=f(T R, A P, G C F, F M L, C O 2)
$$

Thus, equation 2 can be re-specified explicitly using specific independent variables to capture health outcome as

$$
U M R=\alpha 0 \cdot T A X R E V^{\alpha 1} \cdot A P^{\alpha 2} \cdot G C F^{\alpha 3} \cdot F M L^{\alpha 4} \cdot C 02^{\alpha 5} \cdot \mu
$$

Equation 3 depicts a typical heath production function as proposed by Grossman (1972). However, before the regression analysis, the model needs to be linearized or transformed by taking the logarithm of equation 3 to obtain equation 4 below:

$$
\ln U M R=\alpha_{0}+\alpha_{1} \operatorname{InTAXRV}+\alpha_{2} \operatorname{InAP}+\alpha_{3} \operatorname{InGCF}+\alpha_{4} \operatorname{InFML}+\alpha_{5} \operatorname{InCO}+U t
$$

Where: $U M R$ means Under-five Mortality Rate; TR means Tax Revenue; AP means Value of Agricultural Productivity; GCF means Gross capital formation; FML means Female literacy rate, $\alpha_{0}$ is the constant to be estimated $t$ : Time element to illustrate the time-series structure of the data; $\alpha_{1}, \alpha_{2}, \alpha_{3}, \alpha_{4}$, are parameter estimates of the explanatory variables.

\subsection{Variable Description}

Variables in the model are briefly described in this section and summarised in Table 2.

Under-five mortality rate: Under-five mortality rate (UMR) refers to the probability per 1,000 that a new born baby will die before getting to age five, if subject to age-particular death rates of the predefined year. It is the dependent variable and the most sensitive indicator of health outcome. Children are future leaders in any nation and it is valuable to invest in their wellbeing, health and education for a sustainable economy and society. High child death rate mirrors the nearness of troublesome social, economic, and ecological conditions.

Tax Revenue: Revenue from tax is another channel for domestic resource mobilization in Nigeria since more revenue from tax raises the liquidity capacity of the government and vice versa. As such, taxation increases the possibility of public spending on healthcare services.

Value of Agricultural Productivity: Agriculture value added per worker is a measure of agricultural productivity. Increased agricultural productivity is a key focus of government's diversification drive towards achieving sustainable development goals. Furthermore, agriculture is a source of medical research, providing opportunity for more employment and extension of the personal income tax space. Corinna \& Marie (2006) assert that agriculture is fundamental for good wellbeing that produces nourishment, fibre and materials for haven and can deliver medicinal plants. An expansion in an agricultural productivity infers a more effective circulation of scarce resources.

Female Literacy Rate: Gross enrolment ratio of females in primary school is used as proxy for female literacy rate. It is likewise contended that female literacy is an essential determinant of the health status of infants and children, as well as, the population in general (see Baldacci et al., 2004; World Bank, 2004; Schulz, 1993). Literacy is identified with the status of a woman, her age at marriage, her decision power and capacity to get access to health care services. In developing countries, women play a more vital part in family health and sanitation. Furthermore, female training is emphatically related with infants' wellbeing.

Gross Capital Formation (GCF): Gross capital formation, formally referred to as gross domestic investment, is a fundamental way to enhance health outcomes through increased investment in capital goods and physical infrastructure - electricity, water, roads, health facilities, including health workers. Such investments enhance health outcomes and justify the inclusion of GCF in the model. 
Table 1. Variable description and data sources

\begin{tabular}{|c|c|c|c|}
\hline Variable & Identifier & Definition & Source \\
\hline Under 5 Mortality Rate & UMR & $\begin{array}{l}\text { Under-5 mortality rate is the chance in } 1000 \text { births that a } \\
\text { new-born baby will not live to its fifth birthday anniversary. } \\
\text { It has to be based on the age-specific death rate of the specific } \\
\text { year. }\end{array}$ & $\begin{array}{l}\text { World Development } \\
\text { Indicator (WDI) } 2015\end{array}$ \\
\hline Tax Revenue & TAXREV & $\begin{array}{l}\text { Tax revenue implies compulsory payments/transfers to the } \\
\text { government for public expenditure purposes. This does not } \\
\text { include some mandatory payments like social security } \\
\text { contributions, penalties and fines. Repayment of tax } \\
\text { revenues wrongly collected or computed are considered as } \\
\text { negative revenue. }\end{array}$ & $\begin{array}{l}\text { Central Bank of Nigeria } \\
\text { (CBN) } \quad \text { Statistical } \\
\text { Bulletin } 2015\end{array}$ \\
\hline $\begin{array}{l}\text { VALUE of Agricultural } \\
\text { Productivity }\end{array}$ & AP & $\begin{array}{l}\text { Agricultural productivity is computed as total agricultural } \\
\text { outputs divided by total agricultural inputs used to produce } \\
\text { the output }\end{array}$ & $\begin{array}{l}\text { World Development } \\
\text { indicator (WDI) } 2015\end{array}$ \\
\hline Female Literacy Rate & FML & $\begin{array}{l}\text { This is the ratio (stated in percentage) of all females enrolled } \\
\text { in primary schools to the population of females who are } \\
\text { within the official age of primary education }\end{array}$ & $\begin{array}{l}\text { World Development } \\
\text { Indicator (WDI) } 2015\end{array}$ \\
\hline $\begin{array}{l}\text { Gross } \\
\text { Formation }\end{array}$ & GCF & $\begin{array}{l}\text { The Gross Capital Formation of an economy includes all } \\
\text { investments that add to the total fixed assets less reductions } \\
\text { in the inventory level }\end{array}$ & $\begin{array}{l}\text { World Development } \\
\text { Indicator (WDI) } 2015\end{array}$ \\
\hline
\end{tabular}

Source: Authors, 2020

In accordance with the literature, domestic resource mobilization is expected to have a negative impact on under-five mortality rates. It is important to note the expected signs of the parameters, based on economic theory, as $\alpha_{1}, \alpha_{2}, \alpha_{3}$, $\alpha_{4}<0$. This implies that each explanatory variable is expected to have a negative sign and thereby has an inverse relationship with health outcomes. In other words, economic theory indicates that an increase in each explanatory variable will bring about a reduction in under-five mortality - ceteris paribus. The data sources of all the variables incorporated in the model are also tabulated in Table 1.

\subsection{Estimation Technique: Co-integration}

Johansen theory of cointegration as postulated by Johansen and Joselius likes the processes and the concept of equilibrium in the long run (Granger, 1981, 1986; Mill, 1990). This theory is applied as a basis for the analyses in this paper. In this respect, it tests for the long-run between the chosen health outcomes and the independent variables described in section 3.2.

\subsection{Vector Error Correction Model (VECM)}

Short-run adjustment dynamics can be usefully described by the vector error correction model (VECM). The VECM according to Henry and Richard (1983) is of preference as it flexibly and systematically combines both short-run and long-run dynamics. The basic structure of VECM is given as:

$$
\begin{aligned}
D(\operatorname{InUMR}) t= & \beta 0+\beta 1 t D(\operatorname{InT} A X R E V) t-1+\beta 2 t D(\operatorname{InAP}) t-1+\beta 3 t D(\operatorname{InGCF}) t-1+ \\
& \beta 4 t \log D(\operatorname{InFM} L) t-1+\delta V E C M t-1+\mu t
\end{aligned}
$$

Where: $\mathrm{D}=$ difference parameters, VECM is the error correction component of the model

VECM $_{t-1}=$ one period lagged value of the error from the co-integrating initial regression

$\beta_{1}, \beta_{2}, \beta_{3}, \beta_{4}=$ parameter estimates, $\mu_{\mathrm{t}}=$ error term.

Specifically, greater the coefficient of the parameter, the higher the speed of adjustment of the model from the short run to the long run. If actual equilibrium value is too high, the error correction term will reduce it while if it is too low, the error correction term will raise it (Dickey Fuller, 1981). However, the sign of the coefficient must be negative and statistically significant to be acceptable.

\section{Results}

A summary of statistics is presented in 2 in respect of the variables used and the outliers which indicate residual error are identified - especially those with high deviations. Furthermore, it captures the skewness values of the variables - all 
positive except for Under-five mortality rate. The variables have their kurtosis coefficients $>0$ which indicates they are leptokurtic.

Table 2. Summary of descriptive statistics

\begin{tabular}{cccccc}
\hline & UMR & TR & AP & GCF & FML \\
\hline Mean & 179.4571 & 64733.92 & 2112.397 & 12.58818 & 85.43854 \\
Median & 197.0000 & 29.21390 & 1366.936 & 11.74670 & 83.86050 \\
Maximum & 212.6000 & 461224.5 & 4760.310 & 34.02084 & 99.47595 \\
Minimum & 108.8000 & 0.038000 & 685.4052 & 5.467015 & 72.43542 \\
Std.dev. & 36.19679 & 125787.5 & 1402.770 & 6.122224 & 7.800158 \\
Skewness & -0.689853 & 2.098858 & 0.692832 & 1.837585 & 0.282647 \\
Kurtosis & 1.938119 & 6.224250 & 1.910239 & 6.809332 & 1.990531 \\
Jarque-Bera & 4.420473 & 40.85755 & 4.531982 & 40.85941 & 1.952103 \\
Probability & 0.109675 & 0.000000 & 0.103727 & 0.000000 & 0.376796 \\
Sum & 6281.000 & 2265687. & 73933.89 & 440.5864 & 2990.349 \\
Sum sq.Dev. & 44547.07 & 5.380011 & 66903972 & 1274.375 & 2068.644 \\
Observations & 35 & 35 & 35 & 35 & 35 \\
\hline
\end{tabular}

Source: Authors' using E-view

The Johansen process is initiated with the Augmented Dickey Fuller (ADF) Unit Root test for stationarity of the time series and the results are presented in Table 3. Stationarity of all variables at 1st difference can be observed.

Table 3. Results of the Augmented Dickey Fuller Unit Root Test

\begin{tabular}{cccccccc}
\hline Variables & \multicolumn{2}{c}{ ADF test stat } & \multicolumn{3}{c}{ Critical Value } & $\begin{array}{c}\text { Order of } \\
\text { Integration }\end{array}$ & Remarks \\
\hline \multirow{2}{*}{ InUMR } & Level & $1^{\text {st }}$ diff & $1 \%$ & $5 \%$ & P-value & & \\
InAP & - & -5.878420 & -3.724070 & -2.986225 & 0.0001 & $\mathrm{I}(1)$ & Stationary \\
InTAXREV & - & -5.524980 & -3.653730 & -2.957110 & 0.0001 & $\mathrm{I}(1)$ & Stationary \\
InGCF & - & -5.481156 & -3.646342 & -2.954021 & 0.0001 & $\mathrm{I}(1)$ & Stationary \\
InFML & - & -5.741673 & -3.653730 & -2.957110 & 0.0000 & $\mathrm{I}(1)$ & Stationary \\
\hline
\end{tabular}

Source: Authors' using E-views

\subsection{Cointegration Results}

The co-integration test was undertaken based on the maximum likelihood framework of Johannsen (1988) and Johansen and Juselius (1990). This method produces asymptotically optional estimates (as in Table 4). 
Table 4. Co-integration rank estimates

\begin{tabular}{ccccccccc}
\hline Ho & Ha & $\begin{array}{c}\text { Eigen } \\
\text { value }\end{array}$ & $\boldsymbol{\lambda}$ max test & $\boldsymbol{\lambda} \boldsymbol{\operatorname { m a x }}(\mathbf{0 . 9 5})$ & $\mathbf{P}$-Value & Trace test & $\mathbf{p}$-value & $\begin{array}{c}\text { Trace } \\
(\mathbf{0 . 9 5})\end{array}$ \\
\hline $\mathbf{r}=\mathbf{0}$ & $\boldsymbol{r}=\mathbf{1}$ & 0.949349 & 86.50122 & 40.07757 & 0.0000 & 224.9153 & 0.0000 & 95.75366 \\
$\boldsymbol{r} \leq \mathbf{1}$ & $\boldsymbol{r}=\mathbf{2}$ & 0.823867 & 50.35904 & 33.87687 & 0.0000 & 138.4141 & 0.0000 & 69.81889 \\
$\boldsymbol{r} \leq \mathbf{2}$ & $\boldsymbol{r}=\mathbf{3}$ & 0.699730 & 34.88910 & 27.58434 & 0.0048 & 88.05506 & 0.0000 & 47.85613 \\
$\boldsymbol{r} \leq \mathbf{3}$ & $\boldsymbol{r}=\mathbf{4}$ & 0.464002 & 24.09327 & 21.13162 & 0.0186 & 53.16595 & 0.0000 & 29.79707 \\
$\boldsymbol{r} \leq \mathbf{4}$ & $\boldsymbol{r}=\mathbf{4}$ & 0.315347 & 18.08623 & 14.26460 & 0.0119 & 29.07268 & 0.0003 & 15.49471 \\
\hline
\end{tabular}

Source: Authors' using E-views

The outcome of the tests in Tables 4 and 5 suggest that there are at most five integrating equations at $0.05 \%$ level of significance. Furthermore, the Max-eigenvalue test indicates five co-integrating equations at the 0.05 level. In conclusion, there exists a long run association amongst the variables of interest. Deriving the long-run equation from the coefficients in Table 4 (reversing their signs) gives equation 6 which is discussed subsequently:

$$
U M R=0.023850 * \text { TAXREV }-0.360133 * A P+1.436376 * F M L+0.794195 * G C F
$$

It follows that the long run impact of a unit change in tax revenue would positively affect infant mortality by a magnitude of 0.023 which does not follow the a priori expectation. However, the t-statistic of 1.55 , from Table 5 implies that the estimate is statistically not significant. By implication, the result reflects the extent to which tax revenue in Nigeria has experienced under-performance; weak capacity for implementation and ineffective administration. Consequently, tax revenue increase has minimal implication for government expenditure on health towards reducing under-5 mortality rate. Furthermore, a unit increase in Agricultural Productivity (AP) implies a long-run negative affect resulting in a decrease of infant mortality by a magnitude of -0.36 which is significant at t-statistic of 2.84 ceteris paribus.

It is noteworthy that the result for female literacy rate (FML) is contrary to a priori expectation. FML affects under-5 mortality positively with a magnitude of 1.436 . But, its t-statistics is significant with a value is 3.5 which is greater than the threshold of 2.

Table 5. Normalized co-integrating result

\begin{tabular}{lcccc}
\hline \multicolumn{5}{c}{ Co-integrating Equation Log likelihood } \\
Normalized co-integrating coefficients (standard error in parentheses) \\
\hline \multicolumn{1}{c}{ Under-5 Mortality Rate } & TAXREV & AP & FML & GCF \\
1.000000 & -0.023850 & 0.360133 & -1.436376 & -0.794195 \\
S.E & $(0.01534)$ & $(0.12689)$ & $(0.40918)$ & $(0.07238)$ \\
T-Stat & 1.554759 & 2.838151 & 3.510377 & 10.972575 \\
\hline
\end{tabular}

Source: Authors' using E-views

Although, increased female literacy should theoretically bring about decrease in under-5 mortality rate, empirical evidence suggests otherwise. An explanation for this is that educated women, especially in the rural Africa, lack freedom of expression and decision-making authority. This could be another reason why increased female literacy remains an ineffective tool for reducing under-five mortality rate. Therefore, highlighting the importance of educating and empowering female children. Government healthcare expenditure could be extended to enlighten and train females on personal hygiene, infant upbringing, and general healthcare towards reducing the risks of infant death due to carelessness or neglect.

Lastly, the model depicts that in the long run gross capital formation positively affects infant mortality rate by 0.794 . In other words, as gross capital formation increases, the rate of under-five mortality will also rise. Although negative relationship is desirable theoretically, it is statistically significant since its t-statistic value of 10.97 is greater than the threshold of 2. The outcome holds true for Nigeria because infrastructure has been poorly financed overtime and public 
service mismanagement has greatly affected the health sector - dominated by obsolete technology, low capacity building and strikes - thereby affecting the ability "capital" to reduce under-5 mortality.

The model estimates suggest some improvements in Nigeria's tax revenue is feasible from the agricultural sector but a closer examination reveals slower growth rate in tax revenue. There is no convincing argument for expansion in domestic agriculture resource mobilization in Nigeria unless increased agricultural productivity spills-over significantly into agro-allied industries. More so, the industrial, manufacturing and corporate activities are very limited and untaxed. It follows, therefore, that the major challenges to equitable and efficient healthcare financing in Nigeria are dwindling revenue and misappropriation of revenue away from the health sector - which explains the infinitesimal effect of tax revenue on under-five mortality rate. Furthermore, Nigeria's economic growth has been non-inclusive. Consequently, high unemployment widens the spread of poverty, thereby worsening under-five mortality rate.

\section{Summary and Conclusion}

In summary, the study considered domestic resource mobilization and health outcome (UMR) in Nigeria from the period of 1981-2015 with a focus on increased agricultural productivity. Other explanatory variables analysed are tax revenue, gross capital formation, and female literacy rate. The positive relationship between tax revenue and under5 mortality found in the study is a true reflection of the health system in Nigeria. Though, available data generally indicates annual increase in tax revenues, further analysis reveals poor growth rate. In fact, key challenges to equitable and efficient healthcare financing in Nigeria are dwindling budgetary allocation to the sector, lack of political commitment to healthcare provision and high prevalence of systemic corruption. All these factors collectively explain the insignificant effect of tax revenue on under5 mortality.

Furthermore, domestic resource mobilization is challenged by a narrow tax base with potential for increased agricultural productivity. However, most of Nigeria's population are engaged in the informal sector while some others are unemployed. In fact, industrial, manufacturing and general corporate activities are very limited, while the informal sector accounts for around 90 percent of employment and close to half of total economic activities (Adamu, 2006) with $30 \%$ of new entrepreneurs (IMF, 2017). Many business activities in the informal sector are untaxed. The situation is worsened by the existence of export processing zones - with accompanying tax exemptions, tax evasion, and waivers that fuel corruption thereby limiting resource mobilization for healthcare. Over the past two decades, ironically, funding for global health has grown significantly.

Furthermore, the result shows relationship between agricultural productivity - a potentially important source of domestic revenue - and health outcomes in Nigeria. Agricultural value addition requires/involves investment in agro-industries that result in job creation, income generation, and platform for medical research - avenues for domestic resource mobilization. However, the positive relationship between female literacy and under5 mortality differs from the result obtained in Ghana - where higher maternal education significantly reduces the incidence diseases among under-5 children. Although the empirical outcome is contrary to theory, the content and effectiveness of female education becomes questionable - especially in rural areas. Towards correcting this anomaly, the curriculum for female education could be reviewed to emphasize infant health and hygiene. Regarding maternal mortality, a similar finding was obtained and the study suggests "health education tailored toward community culture". Finding that under-five mortality increases with gross capital formation indicates that additional infrastructure for the health sector - like accommodation for health workers, medical laboratories, updating health technology, electricity, clean water and emergency services in the rural areas.

Considering the direct link between health workers' productivity and health sector governance, enhanced funding could be aimed at better management of available resources. Below are suggestions of how results of this study could be useful to different stakeholders in the health and agricultural sectors. First, towards better management of the sector, governments' assessment of healthcare services can be based on quantifiable changes in sickness weights, reduction in malnutrition (among under-5 children), mortality, and affordability of healthcare - rather than focusing on number of hospitals built or number of hospitals renovated; and quantity of pharmaceuticals products received/distributed. Given the observed relationship between domestic resource mobilization and health indices, new fiscal policies could be introduced by government to harness revenue opportunities in informal agriculture sector.

Partnership between private and public sectors is essential for managing the agriculture-tax-health nexus. Collaborative actions are required in agriculture to improve the efficiency of post-harvest value chain thereby, reducing malnutrition and under-5 mortality. Government could grant tax holidays or tax-breaks to private hospitals in rural communities where interventions are needed because of higher rates of under-five deaths. Meanwhile, it will be necessary to review the curriculum for girl-child education which offers less than in-depth training in personal hygiene and nutrition towards maternal and under-5 healthcare. This will involve collaboration among healthcare providers, 
managers of healthcare and educational sectors in Nigeria. For instance, Nigeria's ministry of health could identify curricula needs, while the education ministry will develop and implement curricula that meets the needs in primary and secondary schools.

In conclusion, this study has provided reliable evidence of the effects of domestic agricultural resource mobilization and health outcome (under-five mortality) in Nigeria from the period of 1981-2015. Tax revenue, agricultural productivity, gross capital formation and female literacy were the explanatory variables while under-5 mortality was the dependent variable. It will be reasonable for government to attract more investments in the agricultural sector which will serve as a means of income for households, tax revenue and provision of drugs

\section{Acknowledgement}

The Authors appreciate the publication support from Covenant University Centre for Research, Innovation and Discovery (CUCRID).

\section{References}

Adeloye, D., David, R., Olaogun, A., Auta, A., Adesokan, A., Gadanya, M., \& Iseolorunkanmi, A. (2017). Health Workforce and Governance: The Crisis in Nigeria. Human Resources for Health, 15(32), 1-9.

African Development Bank. (2013). Annual Report for 2013. African Development Fund.

Amusa, K., Monkam, N., \& Viegi, N. (2015). Can Foreign Aid Enhance Domestic Resource Mobilization efforts in Nigeria? Department of Economics, University of Pretoria.

Anand, S., \& Ravallion, M. (1993). Human Development in Poor Countries: The Role of Private Incomes and Public Services. Journal of Economic Perspectives.

Anyawu, J., \& Andrew, E. O. (2007). Health Expenditure and Health Outcomes in Africa. African Development Bank Economic Research Paper, 12-15.

Arize, A. C., \& Melindreros, J. (2008). Dynamic Linkages and Granger Causality between Trade Deficits and Budget Deficits: Evidence from Africa. African Journal of Accounting, Economics, Finance and Banking Research, 2(2).

Ashraf, N., Glaeser, E., Holland, A., \& Steinberg, B. M. (2017). Water, Health and Wealth. NBER Working Paper No. 23807, September. Retrieved August 1, 2018, from http://www.nber.org/papers/w23807

Azuh, D., Azuh, A., Iweala, E., Adeloye, D., Akanbi, M., \& Mordi, R. (2017). Factors influencing Maternal Mortality among Rural Communities in Southwestern Nigeria. International Journal of Women's Health, 179-188.

Baldacci, E. (2004). Social Spending, Human Capital and Growth in Developing Countries: Implication for achieving MDGs. IMF Working paper.

Batyra, A. (2012). Challenges in Domestic Resource Mobilization in the less Developed Countries. LDC IV Monitor, $1-20$.

Bidani, B., \& Ravallion, M. (1995). Decomposing Social indicator using Distributional Data. Policy Research Department, World Bank.

Bloom, D., Canning, D., \& Sevilla.J. (2004). The Effect of Health on Economic Growth: A Production Function Approach. World Development, 32, 1-19.

Bokhari, S. A., Gai, Y., \& Gottret, P. (2007). Government Health Eexpenditure and Health Outcomes. Health Economics, 13(3), 257-273.

Bossert, T. (2010). Institutional Capacities and Decentralization of Health systems in Latin America: Need for More Evidence. Americas Quarterly Summer.

Carr, D. (2004). Improving the Health of the World's Poorest People. PRB Policy Brief, Washington DC: Population Refrence Bureau. Retrieved August 1, 2018, from https://assets.prb.org/pdf04/ImprovingtheHealthbrief_Eng.pdf

Central Bank of Nigeria. (2014). Annual Statistical Bulletin.

Culpeper, R. (2008). Enhancing Domestic Resource Mobilization. G-24 Policy Brief, 25, 1-3.

Culpeper, R., \& Bhusan, A. (2008). Domestic Resource Mobilization: A Neglected Factor in Development Strategy. Background Paper prepared for Workshop on Domestic Resource Mobilization in Sub-Saharan Africa in Entebbe, Uganda May 27-28 
Currie, J., \& Moretti, E. (2003). Mother's Education and the Intergenerational Transmission of Human Capital: Evidence from College Openings and Longitudinal Data. NBER Working Paper No.9360.

Cyprus, R. (2015). Domestic Resource Mobilization. A Discussion Paper Prepared for G20 Development Working Group $(D W G), 2-13$.

David, E. B., Canning, D., \& Sevilla, J. (2003). The Demographic Dividend: A new Perspective on the Economic Consequences of Population Change. RAND.

Deaton, A. (1990). Savings in Developing Countries: Theory and practice. Proceedings of the World Bank Annual Conference on Development Economics. Washington DC: The World Bank.

Deolalikar, A. (2005). Attaining the Millennium Development Goals in India: How likely and What will it take to reduce Infant Mortality, Child Malnutrition, Gender Disparities and Hunger-poverty and to increase School Enrolment and Completion. Washington DC: World Bank.

Dolan, P. P. (2003, September). Grossman's theory of the Demand for Healthcare. Health Economics, 1-8.

Dubosse., N. (2008). The IMF, Fiscal Space and Development Programmes. Brettonwoods Project.

Efanga. S. I., \& Nwokomah, J. M. (2013). Investment in Human Capital for Sustainable Development in Nigeria. Educational Research International, 2(2),134-138.

Engle, R. F., \& Granger, C. W. J. (1987). Cointegration and Error Correction: Representation Estimation and Testing. Econometrica, 55, 251-276.

Ezeh, O., Agho, K., Dibley, M., Hall, J., \& Page, A. (2015). Risk factors for Post-neonatal, Infant, Child and under-5 Mortality in Nigeria: a pooled cross-sectional analysis. BMJ Open, 1-10.

Fakile, A. S., Adegbie, F. F., \& Faboyede, O. S. (2014). Mobilizing Domestic Revenue for Sustainable Development in Africa. European Journal of Accounting Auditing and Finance Research, 2(2), 91-108.

Fan. S., \& Saurkar, A. (2008). Public Spending in Developing Countries: Trends, Determination and Impact.

Federal Ministry of Health. (2004). Health Sector Reform Program: Strategic Thrusts and Log Frame.

Filmer, D., \& Pritchett, L. (1999). The Impact of Public Spending on Health: Does Money Matter?. Social science and Medicine, 49(10), 1309-1323.

Finlay, J. (2007). The Role of Health in Economic Development. Program on the Global Demography of Aging. Working paper, 21, 1-21.

Fleegler, E. (2006). The Twin Deficits Revisited: A Cross-Country Empirical Approach. Being honours thesis submitted in partial fulfillment of the requirements for graduation with distinction in Economics in Trinity college of Duke University.

Gakidou, K., \& King, G. (2000). An Individual Level Approach to Health Inequality: Child Surivival in 50 countries. Global programme on evidence for health policy discussion paper No.18.

George, T. A., \& Gupta, S. (2002). Governance, Corruption and Economic Performance. International Monetary Fund, September 23, 2002.

Gershon, O., \& Patricia, O. (2019). Carbon $\left(\mathrm{CO}_{2}\right)$ footprint determination: An empirical study of families in Port Harcourt. Journal of Physics: Conference Series 1299(1).

Grand, J. L. (1987). Inequalities in Health: Some International Comparisons. European Economic Review, 31, 182-191.

Granger, C. W. (1986). Development in the Study of Co-integrated Economic Variables. Oxford Bulletin of Economic and Statistics, 48(3), 213-228.

Grigoli, F., \& Kapsoli, J. (2013). Waste not, want not: The efficiency of Health Expenditure in Emerging and Developing Economies. IMF working paper. No 13/187.

Grossman, M. (1972a). The demand for health: A Theoretical and Empirical Investigation. New York Columbia (for the National Bureau of Economic Research).

Grossman, M. (1972b). On the Concept of Health Capital and the Demand for Health. Journal of Poliitical Economy, 8, $223-255$ 
Gupta, M. (2003). A Critical Appraisal of Evidence-based Medicine: Some Ethnical Considerations. Journal of Evaluation in clinical practice, 9(2), 111-121.

Gupta, S., Verhoeven, M., \& Tiongson, E. (1999). Does Government Spending buy better Results in Education and Healthcare? IMF Working paper No.WP/99/21. International Monetary Fund, Washington, D.C.

Gupta. S., Verhoeven, M., \& Tiongson, E. (2001). Public Spending on Healthcare and the Poor. IMF working paper, fiscal affairs apartment.

Hansoti, B., Levine, A., Ganti, L., Oteng, R., DesRosiers, T., Mordi, P., \& Brown, J. (2016). Funding Global Emergency Medicine Research - from Seed Grants to NIH Support. International Journal of Emergency Medicine, 1-7.

Harro, \& Domar. (1948). Towards a Dynamic Economics: Some recent Developments of Economic Theory and their Application to Policy. London: Macmillan.

Harrod, \& Domar. (1939). An essay in dynamic theory. Economic Journal, 49, 14-33.

Hawkes, C., \& Ruel, M. (2006). The Links between Agriculture and Health: an Intersectoral opportunity to improve the Health and Livelihoods of the Poor. International Food Policy Research Institute, Bulletin of the World Health Organization, 985-991.

Hendry, R. F. E., \& Richard, J. F. (1983). Exogenity. Economerica, 51(2), 277-304.

HERFON. (2006). Nigeria Health Review. Health Reform Foundation of Nigeria. Ibadan: Kenbim Press Ltd, 10-12, 130-191.

Hojman, D. (1996). Economic and other Determinants of Infant and Child Mortality in Small Developing Countries: The Case of Central America and the Caribbean. Applied Economics, 28, 281-290.

Ichoku, H., \& Okoli, C. I. (2015). Fiscal Space for Health Financing in Nigeria. African Journal of Health Economics, $1-18$.

Ijaz, Z. (2012, July). Impact of Female Literacy Rate and Health Facilities on Infant Mortality Rate in Pakistan. International Journal of Humanities and Social Science, 2(13).

International Monetary Fund (IMF). (2017, April). Sub-Sahara Africa: Restarting the Growth Engine. Regional Economic Outlook.

Jhingan, M. L. (2007). Advanced Economic Theory (Twelfth Revised and Enlarge Edition). Vrinda publications LTD, pp. 1074-1075.

Johansen, S., \& Juselius, K. (1990). Maximum Likelihood estimation and inference on cointegration-with applications to the demand for money. Oxford Bulletin of Economics and Statistics, 169-210.

Johansen. (1988). Statistical Analysis of Cointegration Vectors. Journal of Economic Dynamics and Control, North Holland, 231-254.

Kageyama, J. (2003). The effects of a continouns increase in lifetime on savings. Review of Income and Wealth, 49(2), 163-183.

Kagina, \& Allen. (2012). Aid as a Catalyst to Increase Domestic Revenue Mobilization in Sub-Saharan Africa. Background study for the 2012 DCF-Aid as a catalyst, Development Cooperation Policy, United Nations Economic and Social Council (ECOSOC).

Ke, X., Saksena, P., \& Holly, A. (2011). The Determinants of Health Expenditure: A Country-level Panel Data Analysis. Publication and Resources Working Papers.

Kim, K., \& PM, M. (1992). More Resources better Health? A Cross-national Perspective. US National Library of Medicine-National Insitutes of Health, 34(8), 837-42.

Kotlikoff, L. J. (1988). Intergenerational Transfers and Savings. Journal of Economic Perspectives Spring, 2, 41-58.

Lee, R., Mason, A., \& Miller, T. (2000). Life-Cycle Saving and the Demographic Transition: The Case of Taiwan. Population and Development Review, 194-219.

M.J, R., Hsiao.W, Berman.P, \& Reich.M.R. (2004). Getting Health Reform Right. New York: Oxford University Press. 
Matthew, O., Osabohien, R., Fasina, F., \& Fasina, A. (2018). Greenhouse gas emissions and health outcomes in Nigeria: Empirical insight from ARDL technique. International Journal of Energy Economics and Policy, 8(3), 43-50.

Modigliani, F. (1986). Life cycle, Individual Thrift, and the Wealth of Nations. American Economic Review, 76(3), 297-313.

Musango, L., Nabyong, J., Elovainio, R., \& Cheruiyot. (2013). State of Health Financing in the African Region. World Health Organisation, Regional Office for Africa, 5-46.

Musgrave, R. (1996). The Role of the State in Fiscal Thoery. International Tax and Public Finance, 3(3), 247-258.

Mushtaq.H.khan. (2007.). Governance, Economic Growth and Development since the 1960s. DESA Working Paper No.54, August 2007.

Ndikumana, L. (2015). Savings, Capital flight and African Development. Oxford Handbook of Africa and Economics (Vol. 2). Oxford University Press.

Nkang, N. M., Abang, S. O., Akpan, O. E., \& Ofon, K. J. (2006). Co-integration and Error Correction Modelling of Agriculture Export Trade in Nigeria: The Case of Cocoa. Journal of Agriculture and Social Sciences, 249-255.

Nketiah-Amponsah, E., Boakye-Yiadom, L., \& Agyemang, M. (2016). The Effect of Maternal Education on Child Health: Some Evidence from Ghana. International Journal of Economics and Business Research (IJEBR), 11(4), 366-385.

Nnanna, O. (2003). Promoting savings and investment culture for National Development. Central Bank of Nigeria Economic and Financial Review, 4(3).

North, South \& Institute. (2010). Domestic Resource Mobilization. The North-South Institute, Ottawa, Canada.

Nwachukwu, T. E., \& Egwaikhide, F. O. (2007). An Error-Correction Model of the Determinants of Private Saving in Nigeria. A paper presented at the African Economic Society (AES) Conference, July 2007.

Nwachukwu, T. E., \& Odigie, P. (2009). What Drives Private Saving in Nigeria. A Paper presented at the Centre for the Study of African Economies (CSAE) Conference, University of Oxford, March 2009.

Obrizan, M., \& Wehby, G. L. (2012). Health Expenditures and Life Expectancy around the World: A Quantile Regression Approach. Kyiv School of Economics and Kyiv Economics Institute, Discussion Paper Series.

Ogunleye, E., \& Fashina, D. A. (2012). The Imperatives for Domestic Resource Mobilization for Sustained Post-crisis Recovery and Growth in Sub-Saharan Africa. African Center for Economic Transformation, 1-23.

Olaniyan, O., Onisanwa, I. D., \& Oyinlola, A. (2013). Healthcare Expenditure in Sub-Saharan African Countries: Evidence from Panel Data. Paper submitted for presentation at the 2013 centre for the study of African Economies Conference on Economic Development in Africa, March 2013.

Oluwatoyin. A, M., Folsade. B, A., \& Fagbeminiyi, F. F. (2015). Public Health Expenditure and Health Outcomes in Nigeria. International Journal of Financial Economics, 4(1), 45-56.

Osabohien, R., Matthew, O., Aderounmu, B., \& Olawande, T. I. (2019). Greenhouse gas emissions and crop production in West Africa: Examining the mitigating potential of social protection. International Journal of Energy Economics and Policy, 9(1), 57-66.

Osabohien, R., Matthew, O., Gershon, O., Ogunbiyi, T., \& Nwosu, E. (2019). Agriculture development, employment generation and poverty reduction in West Africa. The Open Agriculture Journal, (13), 82-89.

Otsuka, K., Estudillo, J., \& Yamano, T. (2010). The role of labour markets and human capital in poverty reduction: Evidence from Asia and Africa.

Oyinlola, M. A., Adedeji, A. A., Bolarinwa, M. O., \& Olabisi, N. (2020). Governance, domestic resource mobilization, and inclusive growth in sub-Saharan Africa. Economic Analysis and Policy, 65, 68-88.

Preker, A. S, Carrin, G., Dror, D., Jakab, M., Hsiao, W., \& Arhin-Tenkorng, D. (2004). Rich-poor Differences in Healthcare Financing. In Preker, A. S., \& Carrin, G. (Eds.), Health Financing for Poor People: Resource Mobilization and Risk-sharing. Wahington D.C: The World Bank.

Riman, H. B., \& Akpan, E. S. (2012). Healthcare Financing and Health Outcomes in Nigeria: A State-level Study using Multivariate Analysis. International Journal of Humanities and Social Science, 2(15), 296-309. 
Robert, M. S. (1956, February). A Contribution to the Theory of Economic Growth. The Quarterly Journal of Economics, 70(1), 65-94.

Samy, Y., \& Bhushan, A. (2010). Progress and Missteps in Foreign aid Plans.

Sassi, F., Gran, J. L., \& Archard, L. (2001). Equity versus efficiency: A dilemma for the National health scheme. British Medical Journal, 323, 762-763.

Schneider, F. (2007, July 24). Shadow Economies and Corruption all over the World: New Estimates for 145 Countries. The Open Access, Open Assessment E-Journal.

Tang, C. F. (2010). An Examination of the Government Spending and Economic Growth nexus for Malaysia using the Leveraged Bootstrap Approach. Global Economic Review, 38(2), 215-227.

Terence, H. H., \& Gubhaju, B. (1986). Multivariate Analysis of Infant and Child Mortlaity in Java and Bali. Journal of Biosocial Science.

Travis, P., Bennett ,S., Haines, A., \& Pang, T. (2004). Overcoming health-systems constraints to achieve the milennium development Goals. Pubmed.gov, 900-6.

Ubi, P. S., \& Effiom, L. E. (2015). Domestic Resource Mobilization and Industrial Output in Nigeria. West African Financial and Economic Review, 13(2), 4-15.

United Nations (UN). (2017). Progress towards the Sustainable Development Goals, Report of the Secretary General submitted on $10^{\text {th }}$ May, 2017.

United Nations. (2007). World Population Prospects (The 2000 Revision). New York: United Nations.

World Bank. (2014). World Development Indicator for 2014.

World Health Organization. (2009). Achieving Health Equity: from Root Causes to Fair Outcomes. Interim Statement. Commission on Social Determinants of Health.

World Health Organization. (2015). World Health Statistics 2015.

World Health Report. (2002). Reducing Risks, Promoting Healthy Life. World Health Organization.

World Health Report. (2006). Working together for Health. World Health Organization.

World Health Report. (2013). Health System Financing. The Path to Universal Coverage. Retrieved 9th November 2013, from http://www.who.int/whr/2010/whr10_en.pdf

Wujung, Andrew, Y., Aziseh, \& Isiah, F. (2015). Assessing the Effect of Domestic Resource Mobilization on the Economic Growth of Cameroon. The IEB International Journal of Finance.

Yaya, S., Ekholuenetale, M., Tudeme, G., Vaibhav, S., Bishwajit, G., \& Kadio, B. (2017). Prevalence and Determinants of Childhood Mortality in Nigeria. BMC Public Health, 17(485), 1-7.

Yesufu, M. (2000). The Human Factor in National Development. Spectrum Books, 17-21. 